\section{Risk factors for infant mortality in a municipality in southern Brazil: a comparison of two cohorts using hierarchical analysis}

\author{
Fatores de risco para mortalidade infantil em \\ município do Sul do Brasil: comparação de \\ duas coortes em análise hierarquizada
}

Hellen Geremias dos Santos 1

Selma Maffei de Andrade 1

Ana Maria Rigo Silva 1

Wladithe Organ de Carvalho 1

Arthur Eumann Mesas 1

1 Programa de Pós-graduação
em Saúde Coletiva,
Universidade Estadual de
Londrina, Londrina, Brasil.
Correspondence
S. M. Andrade
Programa de Pós-graduação
em Saúde Coletiva,
Universidade Estadual de
Londrina.
Rua Sergipe 1639, apto. 201,
Londrina, PR
86038-350, Brasil.
selmaffei@gmail.com

Abstract

This study compared risk factors for infant mortality in 2000-2001 and 2007-2008 in Londrina, Paraná State, Brazil. Data on live births and infant deaths were linked in a single database, and a hierarchical regression model was used. Distal risk factors for infant mortality in 2000-2001 were maternal age $<20$ or $\geq 35$ years and lower maternal schooling. In 2007-2008, maternal age $\geq 35$ or $<20$ years were risk factors, while low schooling appeared as a protective factor. The following intermediate factors were associated with increased infant mortality in 2000-2001: multiple pregnancy, history of stillbirth, and insufficient number of prenatal visits, while cesarean delivery was a protective factor. Multiple pregnancy was the only intermediate risk factor in 2007-2008. All of the proximal factors were associated with higher infant mortality in 2000-2001, but only gestational age and 5-minute Apgar in 2007-2008. The risk factors for infant mortality changed from the first to the second cohort, which may be related to the expansion of social policies and primary care and changes in the reproductive and social patterns of Brazilian women.

Infant Mortality; Risk Factors; Information Systems

\section{Introduction}

The reduction of infant mortality has been one of the key priorities of Brazilian health and social policies for several decades. The creation of the Brazilian Unified National Health System (SUS) was followed by an important improvement in access to health services and quality of healthcare in Brazil. Further strides occurred in the first decade of the $21^{\text {st }}$ century, especially with investments in human resources, science and technology, and primary care, with relevant implications for neonatal care and the organization of care for pregnant women and newborn infants 1 . Thus, 1990 to 2007 witnessed an important decline in infant mortality in all regions of Brazil, especially among the poorer population, due to improvements in socioeconomic conditions, urban infrastructure, and healthcare 2,3.

Nevertheless, a large proportion of infant deaths are still avoidable through adequate prenatal, childbirth, and neonatal care ${ }^{4}$. The identification of factors involved in the causal chain of infant death is crucial for understanding the health conditions of the maternal and child population and for defining priority actions.

Studies based on secondary data have identified maternal, healthcare, and neonatal factors as determinants of adverse perinatal outcomes and have helped improve the quality of the respective data sources 5,6 . These contributions have encouraged the use of existing information 
systems by health services to monitor risk factors over time and support epidemiological surveillance services using only limited additional resources.

The use of a hierarchical conceptual model to study determinants of infant mortality allows considering determinants that occur prior to the outcome and the possible relationship between these factors, avoiding analyses that treat all the variables at the same level of determination and which reduce or eliminate the effect of factors that act indirectly on the occurrence of infant death 7 .

The current study thus sought to identify and compare risk factors for infant mortality in Londrina, Paraná State, Brazil, in 2000-2001 and 2007-2008, through hierarchical analysis, using data sources routinely collected by health services.

\section{Methods}

The study was conducted in Londrina, a municipality (county) with a population of 506,701 according to the 2010 Population Census (Instituto Brasileiro de Geografia e Estatística. http:// www.ibge.gov.br/home/estatistica/populacao/ censo2010/primeiros_resultados/populacao_ por_municipio.shtm, accessed on 31/Mar/2012). The study compares two non-concurrent cohorts consisting of live born infants of mothers living in the municipality. The first two-year period (20002001) was selected because it immediately followed the creation of the Municipal Committee for the Prevention of Maternal and Child Mortality (CMPMMI) in 1999 and preceded the implementation of the Family Health Program (FHP) in the municipality in late 2001. The second period (2007-2008) was the most recent one with available data on live births and infant deaths at the time the data were collected for the study. The data were grouped in two-year periods in order to increase the rates' stability and allow more detailed analyses.

The study drew on databases from the Information System on Live Births (SINASC) and the Mortality Information System (SIM) and reports on investigation of infant deaths completed by the CMPMMI. The SINASC data, corresponding to the study's two-year periods, were obtained from the website of the Information Technology Department of the SUS (DATASUS. http:// tabnet. datasus.gov.br/cgi/deftohtm.exe?sinasc/cnv/ nvPR.def, accessed on 23/Aug/2010). The live birth records for mothers living in Londrina and who had given birth in the State of Paraná, which represented more than $99 \%$ of the live births in the Municipality of Londrina, were selected and disaggregated using the Tabwin software (DATASUS. http://portal.saude.gov.br/portal/se/datasus/area.cfm?id_area=732). Next, Microsoft Excel (Microsoft Corp., USA) was used for the data organization and tabulation.

Infant deaths (under one year of age) were identified in the SIM and CMPMMI for the years 2000 to 2002 and 2007 to 2009. The CMPMMI records were examined manually and allowed obtaining the recording number from the Live Birth Certificate (LBC) for 2000-2001, a field which was not available at the time in the SIM database. These records were preferred over those from the SIM in cases of discordant data.

Infant deaths were correlated with the live birth database using deterministic linkage ${ }^{8}$, using the LBC number as key information. In only five cases there was no information available on the LBC number, but it was possible to perform linkage between the deaths and live births based on identical information in both databases for date of birth and maternal, gestational, and neonatal characteristics.

The dependent variable was infant death, and the independent variables were those available in the SINASC database in both two-year periods: maternal age, schooling, and marital status, newborn's race/skin color, obstetric history, number of prenatal visits, type of pregnancy, type of delivery, gestational age, birth weight, 5-minute Apgar score, and newborn's gender. The analysis did not include presence of congenital malformations because of the low reliability of this information in the SINASC database based on analysis of matching three data sources, or the 1-minute Apgar score, since 5-minute Apgar provides a better indication of the newborn's status 9 .

Maternal schooling was grouped in the SINASC database according to complete years of study: none, 1-3, 4-7, 8-11, and 12 or more. The variable was reclassified for the current study according to the mother's age, as insufficient, intermediate, or high schooling, seeking to classify the schooling as expected for the age bracket, although the previous classification in SINASC had prevented more adequate adjustments. The category "insufficient" included mothers up to 15 years of age with three years of schooling and those 16 years or older with up to seven years of school; "intermediate" referred to mothers up to 15 years of age who had at least four years of school and those 16 or older with at least eight years; the category "high" included mothers with 12 years of schooling or more. In the analysis, the categories "insufficient" and "intermediate" were grouped into a single category, called "low schooling", versus the category "high schooling". 
"Number of prenatal visits" was reclassified as sufficient or insufficient according to gestational age, based on the prenatal care protocol of the Londrina Municipal Health Secretariat (Secretaria Municipal de Saúde de Londrina), Clinical Health Protocols: http://www1.londri na.pr.gov.br/index.php?option=com_content\& view $=$ article \&id $=569 \&$ Itemid $=615$ (accessed on 23/Aug/2011). Sufficient was defined as at least one prenatal visit for pregnancies up to 27 weeks, at least four visits for pregnancies from 28 to 36 weeks, and at least seven for pregnancies 37 weeks or more. Both variables (prenatal visits and gestational age), from the SINASC database, had been previously grouped.

The variable "obstetric history" was defined by cross-analyzing the variables "number of live births" and "number of stillbirths". The following categories were considered: with or without stillbirths, where the latter was subdivided into primiparous, 1 or 2 live births and no stillbirths, and mulitparous (3 or more live births) with no stillbirths.

In addition to these groupings, the categories for the variable "newborn's race/skin color" were grouped into White/Asian versus Black/Brown/ Indigenous, and the categories for the variable "marital status" were grouped as with versus without spouse/companion, both of which were indicative of socioeconomic differences.

Statistical analyses used SPSS 19.0 (SPSS Inc., Chicago, USA). Measure of association was odds ratio (OR) for both the bivariate analysis and the binary logistic regression conducted by the hierarchical conceptual model, using the backward stepwise method (likelihood ratio). For definition of the hierarchical conceptual model, the variables were grouped as distal (socio-demographic characteristics), intermediate (gestational and healthcare characteristics), and proximal (characteristics of the newborn), considering the determinant factors as temporally positioned prior to the outcome (infant death) as shown in Figure 1. All the selected variables were included in the regression model based on their clinical and epidemiological importance. Statistical significance was set at $5 \%$ (Wald test), and for all the variables a reference category was established $(\mathrm{OR}=1)$, considered the lowest risk for occurrence of the outcome. Logistic regression excluded live born infants with some field in the SINASC database that was either missing or coded as unknown.

The study was approved by the Institutional Review Board of the Londrina State University (Universidade Estadual de Londrina; case CEP/ UEL 240/10).

\section{Results}

The study population consisted of 15,385 and 13,208 live born infants in 2000-2001 and 20072008, respectively. The SIM and CMPMMI databases showed 185 and 148 deaths of live born infants, respectively. For the first period, it was possible to link $97.3 \%$ of the infant deaths to their respective LBCs in the live birth database, while in the second period $100 \%$ of the deaths were linked to their LBCs.

Bivariate analysis of the 2000-2001 cohort (Table 1$)$ showed higher odds of death $(p<0.05)$ among infants of mothers $<20$ years or $\geq 35$ years of age, with low schooling, without a spouse/ companion at the time of the child's birth, among Black/Brown/Indigenous newborns, and among those of mothers with insufficient number of prenatal visits, primiparous mothers, or mothers with a history of stillbirth, and infants born of multiple pregnancies. Cesarean delivery appeared as a protective factor. All proximal variables except the newborn's sex were statistically associated with infant death.

In 2007-2008 (Table 1), the following were statistically associated with infant death: maternal age $<20$ or $\geq 35$ years, multiparity with no stillbirths, multiple pregnancy, and all proximal variables except the newborn's sex. Low maternal schooling appeared as a protective factor.

In 2000-2001, adjustment of distal variables in the hierarchical analysis showed the following as risk factors for infant mortality: maternal age $<20$ or $\geq 35$ years and low maternal schooling (Table 2).

All the intermediate variables remained in the model after adjusting for variables at the same level and at the distal level. The subgroups of live born infants whose mothers reported insufficient number of prenatal visits, history of stillbirth, or newborns from multiple pregnancies showed higher odds of death. Meanwhile, cesarean delivery showed less than half the odds of infant death as compared to vaginal delivery (Table 2).

Proximal variables, especially birth weight, showed the greatest impact on infant mortality in 2000-2001. For gestational age, the only category that remained as a risk factor was extreme prematurity $(<28$ weeks). Five-minute Apgar $<4$ and 4 to 6 were also statistically significant risk factors as compared to Apgar $\geq 7$. Male newborns showed $52 \%$ higher odds of dying as compared to females (Table 2).

In 2007-2008, the following socio-demographic variables remained as statistically significant risk factors: maternal age $<20$ years, although with a reduction in the OR when compared to 2000-2001 (from 2.79 to 1.59 ), and $\geq 35$ 
Figure 1

Hierarchical conceptual model for determinant factors of infant mortality based on variables available in the database of the Information System on Live Births (SINASC).

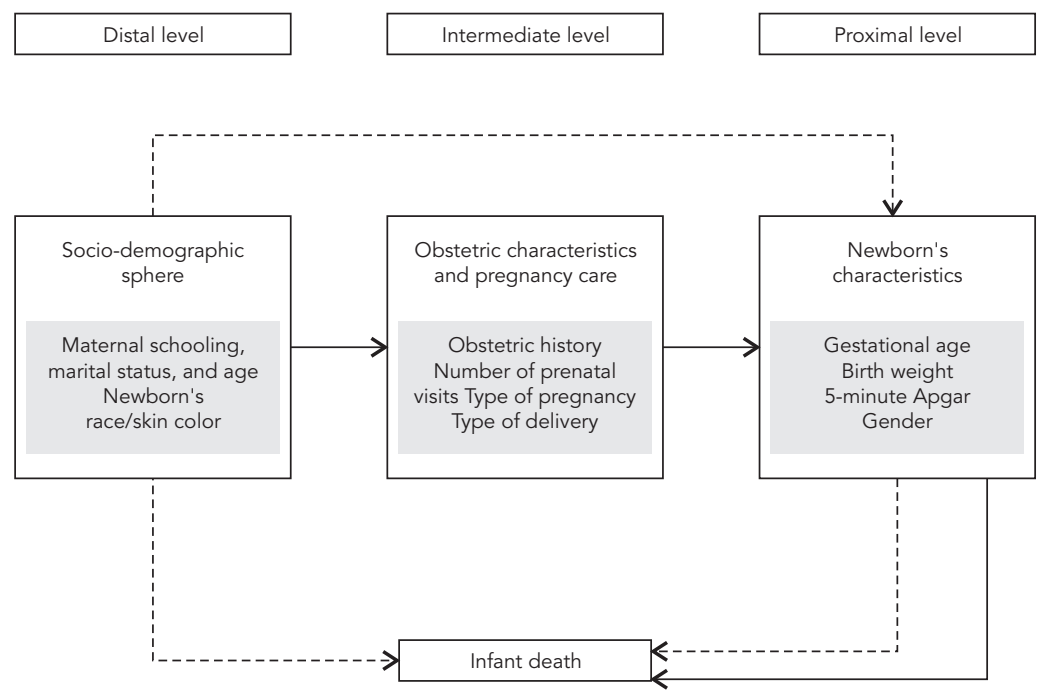

Table 1

Unadjusted risk factors for infant mortality. Londrina, Paraná State, Brazil, 2000-2001 and 2007-2008.

\begin{tabular}{|c|c|c|c|c|c|c|c|c|}
\hline \multirow[t]{2}{*}{ Variables } & \multicolumn{4}{|c|}{$2000-2001$} & \multicolumn{4}{|c|}{ 2007-2008 } \\
\hline & $\begin{array}{c}\text { Total * } \\
(\mathrm{N}=15,385)\end{array}$ & $\begin{array}{l}\text { Deaths * } \\
(n=180)\end{array}$ & $\begin{array}{l}\text { Unadjusted } \\
\text { OR }\end{array}$ & $95 \% \mathrm{Cl}$ & $\begin{array}{c}\text { Total * } \\
(\mathrm{N}=13,208)\end{array}$ & $\begin{array}{l}\text { Deaths * } \\
(n=148)\end{array}$ & $\begin{array}{c}\text { Unadjusted } \\
\text { OR }\end{array}$ & $95 \% \mathrm{Cl}$ \\
\hline \multicolumn{9}{|l|}{ Distal determinants } \\
\hline \multicolumn{9}{|l|}{ Maternal age (years) } \\
\hline$<20$ & 2,832 & 57 & 2.29 & $1.64-3.18$ ** & 2,141 & 31 & 1.52 & $1.01-2.29 * \star \star$ \\
\hline $20-34$ & 10,887 & 97 & 1.00 & - & 9,394 & 90 & 1.00 & - \\
\hline$\geq 35$ & 1,664 & 25 & 1.70 & 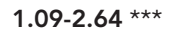 & 1,673 & 27 & 1.70 & $1.10-2.62$ *** \\
\hline \multicolumn{9}{|l|}{ Maternal schooling } \\
\hline Low & 12,767 & 160 & 1.67 & $1.04-2.69 * \star \star$ & 10,375 & 105 & 0.66 & $0.46-0.94$ *** \\
\hline High & 2,518 & 19 & 1.00 & - & 2,800 & 43 & 1.00 & - \\
\hline \multicolumn{9}{|l|}{ Race/skin color } \\
\hline Black/Brown/ & 801 & 26 & 1.73 & $1.14-2.65 * \star \star$ & 1,207 & 18 & 1.38 & $0.84-2.27$ \\
\hline \multicolumn{9}{|l|}{ Indigenous } \\
\hline White/Asian & 8,063 & 153 & 1.00 & - & 11,966 & 130 & 1.00 & - \\
\hline \multicolumn{9}{|l|}{ Marital status } \\
\hline $\begin{array}{l}\text { With spouse/ } \\
\text { companion }\end{array}$ & 12,205 & 131 & 1.00 & - & 7,102 & 77 & 1.00 & - \\
\hline $\begin{array}{l}\text { Without spouse/ } \\
\text { companion }\end{array}$ & 3,123 & 48 & 1.44 & $1.03-2.01$ *** & 6,067 & 71 & 1.08 & $0.78-1.49$ \\
\hline
\end{tabular}

(continues) 


\begin{tabular}{|c|c|c|c|c|c|c|c|c|}
\hline \multirow[t]{2}{*}{ Variables } & \multicolumn{4}{|c|}{$2000-2001$} & \multicolumn{4}{|c|}{$2007-2008$} \\
\hline & $\begin{array}{c}\text { Total * } \\
(\mathrm{N}=15,385)\end{array}$ & $\begin{array}{l}\text { Deaths * } \\
(n=180)\end{array}$ & $\begin{array}{c}\text { Unadjusted } \\
\text { OR }\end{array}$ & $95 \% \mathrm{Cl}$ & $\begin{array}{c}\text { Total * } \\
(\mathrm{N}=13,208)\end{array}$ & $\begin{array}{l}\text { Deaths * } \\
(n=148)\end{array}$ & $\begin{array}{c}\text { Unadjusted } \\
\text { OR }\end{array}$ & $95 \% \mathrm{Cl}$ \\
\hline \multicolumn{9}{|c|}{ Intermediate determinants } \\
\hline \multicolumn{9}{|c|}{ Number of prenatal } \\
\hline Sufficient & 12,086 & 125 & 1.00 & - & 12,069 & 134 & 1.00 & - \\
\hline Insufficient & 3,199 & 54 & 1.64 & $1.19-2.27$ \# & 1,073 & 14 & 1.18 & $0.68-2.05$ \\
\hline \multicolumn{9}{|l|}{ Obstetric history } \\
\hline Stillbirth(s) & 2,051 & 31 & 1.83 & $1.17-2.88 \#$ & 1,560 & 16 & 1.04 & $0.59-1.84$ \\
\hline Primiparous & 6,067 & 81 & 1.62 & $1.13-2.30 \#$ & 5,521 & 65 & 1.20 & $0.82-1.75$ \\
\hline 1 or 2 live births/ & 6,017 & 50 & 1.00 & - & 4,771 & 47 & 1.00 & - \\
\hline \multicolumn{9}{|l|}{ No stillbirths } \\
\hline \multicolumn{9}{|l|}{ No stillbirths } \\
\hline \multicolumn{9}{|l|}{ Type of pregnancy } \\
\hline Single & 15,090 & 161 & 1.00 & - & 12,938 & 126 & 1.00 & - \\
\hline Multiple & 294 & 19 & 6.41 & $3.92-10.46$ ** & 268 & 22 & 9.09 & $5.68-14.55$ ** \\
\hline \multicolumn{9}{|l|}{ Type of delivery } \\
\hline Normal & 7,595 & 112 & 1.00 & - & 5,720 & 59 & 1.00 & - \\
\hline Cesarean & 7,768 & 68 & 0.59 & $0.44-0.80 \#$ & 7,480 & 89 & 1.16 & $0.83-1.61$ \\
\hline \multicolumn{9}{|l|}{ Proximal determinants } \\
\hline \multicolumn{9}{|l|}{ Newborn's gender } \\
\hline Male & 7,934 & 102 & 1.23 & $0.92-1.66$ & 6,746 & 84 & 1.26 & $0.91-1.75$ \\
\hline Female & 7,448 & 78 & 1.00 & - & 6,462 & 64 & 1.00 & - \\
\hline \multicolumn{9}{|c|}{ Gestational age (weeks) } \\
\hline$<28$ & 56 & 43 & 662.70 & $341.59-1285.70$ ** & 73 & 54 & 729.74 & $401.44-1326.52$ ** \\
\hline $28-31$ & 115 & 32 & 77.24 & $48.29-123.56$ ** & 117 & 27 & 77.03 & $45.87-129.36$ ** \\
\hline $32-36$ & 887 & 33 & 7.74 & $5.09-11.77$ ** & 1,148 & 21 & 4.78 & $2.85-8.05 * \star$ \\
\hline$\geq 37$ & 14,296 & 71 & 1.00 & - & 11,857 & 46 & 1.00 & - \\
\hline \multicolumn{9}{|l|}{ Birth weight (grams) } \\
\hline$<1,500$ & 183 & 79 & 187.09 & $126.49-276.73$ ** & 186 & 72 & 155.25 & $103.33-233.27$ ** \\
\hline $1,500-2,499$ & 1,106 & 44 & 10.20 & $6.85-15.20 * *$ & 928 & 27 & 7.37 & $4.58-11.84$ ** \\
\hline$\geq 2,500$ & 14,096 & 57 & 1.00 & - & 12,094 & 49 & 1.00 & - \\
\hline \multicolumn{9}{|l|}{ 5-minute Apgar } \\
\hline$<4$ & 113 & 37 & 67.44 & $43.60-104.31$ ** & 50 & 29 & 194.46 & $106.95-353.57$ ** \\
\hline $4-6$ & 132 & 32 & 44.33 & $28.53-68.88$ ** & 84 & 26 & 63.12 & $38.06-104.70$ ** \\
\hline$\geq 7$ & 15,069 & 108 & 1.00 & - & 13,047 & 92 & 1.00 & - \\
\hline
\end{tabular}

OR: odds ratio; $95 \% \mathrm{Cl}$ : $95 \%$ confidence interval.

* The total number of live births and infant deaths varied according to the number of missing values for each characteristic;

$* * p<0.001 ;$

$\star * \star * 00.05$

$\# p<0.01$. 
Table 2

Hierarchical logistic regression for determinant factors of infant mortality. Londrina, Paraná State, Brazil, $2000-2001$.

\begin{tabular}{|c|c|c|c|c|}
\hline Variables & Total * $(\mathrm{N}=8,587)$ & Deaths * $(n=175)$ & Adjusted OR ** & $95 \% \mathrm{Cl}$ \\
\hline \multicolumn{5}{|l|}{ Distal determinants } \\
\hline \multicolumn{5}{|l|}{ Maternal age (years) } \\
\hline$<20$ & 1,192 & 97 & 2.79 & 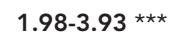 \\
\hline $20-34$ & 6,260 & 53 & 1.00 & - \\
\hline$\geq 35$ & 1,135 & 25 & 1.58 & $1.01-2.47 \#$ \\
\hline \multicolumn{5}{|l|}{ Maternal schooling } \\
\hline Low & 6,304 & 155 & 2.34 & 1.45-3.79 \#\# \\
\hline High & 2,283 & 20 & 1.00 & - \\
\hline \multicolumn{5}{|l|}{ Intermediate determinants } \\
\hline \multicolumn{5}{|l|}{ Number of prenatal visits } \\
\hline Sufficient & 7,129 & 123 & 1.00 & - \\
\hline Insufficient & 1,458 & 52 & 1.48 & $1.04-2.09 \#$ \\
\hline \multicolumn{5}{|l|}{ Obstetric history } \\
\hline Stillbirths & 971 & 31 & 2.03 & $1.28-3.24 \# \#$ \\
\hline Primiparous & 3,578 & 80 & 1.35 & $0.91-2.00$ \\
\hline 1 or 2 live births, no stillbirths & 3,457 & 49 & 1.00 & - \\
\hline Multiparous, no stillbirths & 581 & 15 & 1.22 & $0.66-2.25$ \\
\hline \multicolumn{5}{|l|}{ Type of pregnancy } \\
\hline Single & 8,349 & 156 & 1.00 & - \\
\hline Multiple & 238 & 19 & 5.60 & $3.34-9.38$ *** \\
\hline \multicolumn{5}{|l|}{ Type of delivery } \\
\hline Normal & 2,983 & 107 & 1.00 & - \\
\hline Cesarean & 5,604 & 68 & 0.42 & $0.30-0.58$ *** \\
\hline \multicolumn{5}{|l|}{ Proximal determinants } \\
\hline \multicolumn{5}{|l|}{ Newborn's gender } \\
\hline Male & 4,433 & 100 & 1.52 & 1.04-2.21 \# \\
\hline Female & 4,154 & 75 & 1.00 & - \\
\hline \multicolumn{5}{|l|}{ Gestational age (weeks) } \\
\hline$<28$ & 54 & 42 & 6.63 & 1.85-23.81 \#\# \\
\hline $28-31$ & 112 & 32 & 2.12 & $0.75-5.97$ \\
\hline $32-36$ & 702 & 33 & 1.08 & $0.58-2.02$ \\
\hline$\geq 37$ & 7,719 & 68 & 1.00 & - \\
\hline \multicolumn{5}{|l|}{ Birth weight (grams) } \\
\hline$<1,500$ & 177 & 78 & 22.50 & $8.02-63.09$ *** \\
\hline $1,500-2499$ & 798 & 43 & 5.95 & 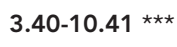 \\
\hline$\geq 2,500$ & 7,612 & 54 & 1.00 & - \\
\hline \multicolumn{5}{|l|}{ 5-minute Apgar } \\
\hline$<4$ & 83 & 36 & 11.89 & $5.88-24.07$ *** \\
\hline $4-6$ & 93 & 32 & 11.52 & $6.12-21.69$ *** \\
\hline$\geq 7$ & 8,411 & 107 & 1.00 & - \\
\hline
\end{tabular}

OR: odds ratio; $95 \% \mathrm{Cl}$ : $95 \%$ confidence interval.

* Live births and infant deaths related to complete data in the Information System on Live Births (SINASC);

** OR adjusted for variables at the same level and higher levels;

$* * * p<0.001$;

$\# p<0.05$

$\# p<0.01$. 
years, with an OR identical to that in the previous period. Low maternal schooling, unlike the first period, appeared as a protective factor against infant death. Among the obstetric and healthcare characteristics, type of pregnancy was the only variable that remained in the model (Table 3 ).

As in the first period, proximal variables had the greatest impact on the outcome, but the newborn's sex and birth weight lost significance. All the categories related to prematurity and low Apgar score $(<4$ and 4 to 6$)$ were statistically significant (Table 3).

\section{Discussion}

The study showed changes in the risk profile for infant mortality from the first to the second cohort. In 2000-2001, markers of social inequality such as low schooling and maternal age less than
20 years played a more important role in this outcome, although newborns of mothers 35 years of age or older already showed increased odds of infant death. The changes detected in the risk factors in the more recent period, like a reduction in the odds of death among newborns of adolescent mothers and an increase among mothers with more schooling, in addition to the persistence of maternal age $\geq 35$ years as a risk factor, suggest a reduction in these inequalities and changes in the women's childbearing and social profile.

Among the socio-demographic variables, in 2000-2001, maternal age $<20$ years was the most important determinant of infant mortality. The association between infant death and teenage pregnancy has been discussed from both the biological and social point of view. The immaturity of the female reproductive system and maintenance of the adolescent's growth and development during pregnancy are examples

\section{Table 3}

Hierarchical logistic regression for determinant factors of infant mortality. Londrina, Paraná State, Brazil, 2007-2008.

\begin{tabular}{|c|c|c|c|c|}
\hline Variables & Total * $(\mathrm{N}=12,326)$ & Deaths * $(n=142)$ & Adjusted OR ** & $95 \% \mathrm{Cl}$ \\
\hline \multicolumn{5}{|c|}{ Distal determinants } \\
\hline \multicolumn{5}{|c|}{ Maternal age (years) } \\
\hline$<20$ & 2,055 & 29 & 1.59 & $1.03-2.46$ *** \\
\hline $20-34$ & 8,771 & 88 & 1.00 & - \\
\hline$\geq 35$ & 1,500 & 25 & 1.58 & $1.01-2.48$ *** \\
\hline \multicolumn{5}{|c|}{ Maternal schooling } \\
\hline Low & 9,867 & 103 & 0.60 & $0.40-0.88 \#$ \\
\hline High & 2,459 & 39 & 1.00 & - \\
\hline \multicolumn{5}{|c|}{ Intermediate determinants } \\
\hline \multicolumn{5}{|c|}{ Type of pregnancy } \\
\hline Single & 12,090 & 120 & 1.00 & - \\
\hline Multiple & 236 & 22 & 10.17 & $6.31-16.40 \# \#$ \\
\hline \multicolumn{5}{|c|}{ Proximal determinants } \\
\hline \multicolumn{5}{|c|}{ Gestational age (weeks) } \\
\hline$<28$ & 68 & 52 & 304.84 & $144.12-644.78$ \#\# \\
\hline $28-31$ & 109 & 27 & 48.74 & 26.34-90.19 \#\# \\
\hline $32-36$ & 1,042 & 20 & 3.86 & 2.19-6.78 \#\# \\
\hline$\geq 37$ & 11,107 & 43 & 1.00 & - \\
\hline \multicolumn{5}{|c|}{ 5-minute Apgar } \\
\hline$<4$ & 49 & 29 & 46.99 & 17.94-123.13 \#\# \\
\hline $4-6$ & 79 & 24 & 14.76 & 6.71-32.47 \#\# \\
\hline$\geq 7$ & 12,198 & 89 & 1.00 & - \\
\hline
\end{tabular}

OR: odds ratio; $95 \% \mathrm{Cl}$ : $95 \%$ confidence interval.

* Live births and infant deaths related to complete data in the Information System on Live Births (SINASC);

** OR adjusted for variables at the same level and higher levels;

*** $p<0.05$

$\# p<0.01$;

$\# \mathrm{p}<0.001$. 
of predisposing biological factors for adverse perinatal outcomes such as intrauterine growth restriction, prematurity, and low birth weight 10 . Teenage pregnancy has also been highlighted as one of the results of worse socioeconomic conditions for the adolescent and her family 11 , a situation that precedes and determines difficulties in access to (and use of) health services and adverse perinatal outcomes 12 .

Low maternal schooling also affects the interdependence between socioeconomic status, access to health services, and vulnerability of the pregnant woman and newborn. In 2000-2001, this factor appeared as a risk for infant mortality, corroborating a study by Geib et al. 13 in Passo Fundo, Rio Grande do Sul State, from February 2003 to January 2004, in which low maternal schooling contributed to the perpetuation of iniquities in infant survival. Women's low schooling is also associated with lower access to adequate prenatal care 14 .

In 2007-2008, newborns of mothers $\geq 35$ years of age showed odds of death similar to infants of teenage mothers. The association between this outcome and advanced maternal age may reflect the increase in the proportion of Brazilian mothers in this age bracket and may represent the biological disadvantages of late pregnancy, generally accompanied by more schooling and higher socioeconomic status, stable marital status, and planned/desired pregnancy ${ }^{15}$. Studies have shown higher odds of gestational diabetes and hypertension with increasing maternal age 16,17 , both of which have direct implications for infant survival. In addition, a review of the effects of maternal age on infant mortality emphasizes the increased likelihood of assisted reproduction techniques among women that choose to postpone motherhood 15 , potentially associated with more multiple pregnancies and maternal complications that predispose to premature labor 18 .

Statistically, low maternal schooling appeared as a protective factor against infant death in 2007-2008, unlike the previous period. Recent studies in Brazil have highlighted a decrease in inequalities in infant mortality according to maternal schooling 19 . This characteristic is associated with the reduction in the infant mortality rate among mothers with less schooling and the rate's stabilization or increase among mothers with more schooling, who are mostly older, more likely to have cesareans, and have a higher proportion of premature and low birth weight infants 19 . This scenario illustrates the changes in Brazilian women's social and reproductive characteristics and healthcare in recent years 3 .

The explanations attributed to socio-demographic factors are strengthened by obstetric and healthcare variables that remained in the model for determination of infant mortality after the hierarchical logistic regression analysis.

Although the data source restricted the interpretation of prenatal care to the number of prenatal visits, and although previously categorized, a study in Salvador, Bahia State, Brazil, using a criterion similar to that of the current study, also identified inadequate number of prenatal visits as a predictor of infant death, a finding attributed to possible difficulties in access to such care 6 . Access to health services involves socioeconomic, cultural, and geographic factors that transcend the availability of healthcare resources and can act singly or jointly to hinder the use of such services 20 . In this context, factors related to quality of prenatal care are important, but were not covered in this study, such as early uptake of pregnant women into prenatal care, the establishment of a bond between the health team and the patient that ensures case resolution in care, linkage to other health services for continuity of care, ordering of tests for the investigation of maternal diseases and conditions, adequate communication of protocols and procedures 3 , and other actions that have been the focus of initiatives for the humanization and qualification of prenatal care.

In 2007-2008, insufficient number of prenatal visits was no longer a predictor of infant mortality. Improvements in the field of social policies and primary care are possible explanations for this finding 1 . Between the first and second periods, the Bolsa Família (Family Grant) Program was created in 2003 in Brazil, conditioned (among other requirements) on mandatory prenatal care attendance by pregnant women 21. Expansion of primary care by the FHP may have contributed to the increased coverage and improvement in prenatal care, by favoring decentralization of primary health services and uptake, follow-up, and referral of pregnant women to other levels of care 22 . In the municipality studied here the number of family health teams (initially only four) was expanded in late 2001 and 2002 to 93 teams, covering $70 \%$ and $100 \%$ of the urban and rural populations, respectively 23 .

According to the current study, the association between history of stillbirth and infant mortality was statistically significant in 2000-2001 but not in 2007-2008, suggesting the importance of the socioeconomic context in the determination of this obstetric antecedent. Almeida et al. 12, after adjusting for socioeconomic, healthcare, and neonatal variables, found a loss of statistical significance in the association between neonatal death and obstetric history in São Paulo, consistent with this hypothesis. 
In the current study, cesarean delivery was a protective factor in 2000-2001 but was not statistically associated with infant mortality in 20072008. Although no analysis was performed on the relationship between type of delivery, maternal age, and schooling, one can hypothesize that the association observed in the earlier two-year period was due more to that birth cohort's socioeconomic characteristics than to the procedure itself. Studies have called attention to socioeconomic differences according to type of delivery: white and older women and those with more schooling and better socioeconomic status (who mainly give birth in private hospitals) are the group that usually undergoes cesarean delivery 24 . The fact that type of delivery did not remain in the explanatory model for infant death in the more recent period may be explained by changes in the socio-demographic and reproductive profile of Brazilian women, as discussed above.

Multiple pregnancies were a risk factor for infant mortality in both periods, and unlike the other intermediate variables, they showed an increase in the odds of infant death in the more recent cohort. A study in Salvador, showed a similar result for early neonatal mortality, also considering type of pregnancy at the intermediate level in the hierarchical model 25. The authors emphasize the importance of special care for women with multiple pregnancies, due to the increased rate of adverse perinatal outcomes such as prematurity and low birth weight in twin pregnancies.

Completing the causal chain for infant death, among the proximal factors, female gender in the newborn only acted as a protective factor in 20002001. Studies on infant mortality 25,26 have also shown this association, which has been attributed to earlier fetal lung maturation in girls and a resulting decrease in the incidence of neonatal respiratory problems 27 . However, more recently, similar to the current study's findings in the latest two-year period, some researchers have detected a reduction in excess male infant mortality in 15 developed countries, attributing this fact to improved obstetric and neonatal care 28 . The loss of this variable's effect in the current context of Londrina may have resulted from expansion of perinatal care, with the hierarchical organization and regionalization of health services and greater access to neonatal technologies such as intensive care and the use of corticosteroids and surfactant in prematurity 28 .

In 2000-2001, very low birth weight $(<1,500 \mathrm{~g})$ appeared as an important category in the determination of infant death, possibly reflecting pregnant women's social and healthcare characteristics during this same period. Very low birth weight, in addition to acting as a marker for worse socioeconomic conditions and worse access to prenatal care ${ }^{5}$, signals the importance of quality of obstetric and neonatal care for very low birth weight infants, who are more vulnerable to various complications and thus depend more heavily for their survival on technology (equipment and highly trained professionals) 12 . A study in a public maternity hospital in the State of Minas Gerais emphasized the relevance of birth weight below $1,000 \mathrm{~g}$ and extreme prematurity (up to 27 weeks gestational age) for early neonatal mortality (up to seven days of life); these two characteristics were the most prevalent among early neonatal deaths and are considered difficult to prevent by the authors 29 .

The current study showed an increase in odds of death for premature newborns, but also a loss of significance for the birth weight variable between the first and second cohort. One possible explanation is the increase in premature births in recent years 30 and the decrease in infants with intrauterine growth restriction, due to the improvement in socioeconomic conditions in Brazil 31, which may have eliminated the statistical significance of birth weight. It is further plausible to assume that this finding is associated with a reduction in the underreporting of live births involving worse prognosis and an improvement in the quality of data on gestational age.

The Apgar score is a simple and useful indicator for estimating neonatal vitality and evaluating responses to resuscitation maneuvers ${ }^{9}$. The increase in the odds of death for newborns with low 5-minute Apgar is consistent with the change in the risk profile for infant mortality between the first and second cohorts.

The more recent infant mortality risk factor profile, in which the proximal determinants gained importance, especially prematurity, highlights the relevance of improving care for women not only during pregnancy, as already discussed, but also during childbirth, guaranteeing the continuity of prenatal care through immediate uptake of women in labor and adequate monitoring, in order for the necessary medical interventions to occur in timely fashion ${ }^{3}$. Neonatal care also needs to be improved. Given the increase in the number of premature live newborns with chances of survival, training human resources in the proper utilization of available technologies and management of adverse situations that require neonatal reanimation 32 are strategic measures to avoid deaths and sequelae and to guarantee survival with quality of life.

Several methodological aspects of this study deserve special attention. The use of information systems for conducting epidemiological studies depends on the degree of coverage of the target 
event, the completeness and detail of the variables in these systems, and their data's validity 33 . In Londrina, studies have identified good quality of data in the SINASC database and a gradual decrease in the rates of missing or unknown data since the system has been implemented ${ }^{34}$. In addition, the application of data linkage and the use of CMPMMI records as an alternative data source on infant death allow improving the data recorded in the SINASC and SIM databases, in relation to both their completeness and plausibility 33 .

Another limitation to the data source used here involves the variables available in SINASC, which fail to include important risk factors for infant death described in the literature, such as domestic violence and maternal illness during pregnancy 35 , low maternal height, pre-gestational weight, maternal smoking, and birth spacing 30 . Still, studies based on secondary data have identified various maternal, healthcare, and neonatal risk factors for infant death and have thus helped raise hypotheses for planning studies based on primary data and for monitoring these characteristics by health services 5,12 . In addition, the analysis and interpretation of independent vari- ables from the logic of a hierarchical conceptual model enhanced the understanding of the role of socio-demographic, healthcare, and neonatal variables in the determination of infant death, thereby reinforcing the importance of this procedure as an alternative to analyses based only on statistical associations 7 .

In short, changes were observed in the risk factors for infant mortality between the two cohorts, which may be related to the expansion of social policies and primary health care and the modifications in Brazilian women's reproductive and social patterns in recent years. There was a decrease in the odds of death for infants of adolescent mothers and those with low schooling. Insufficient number of prenatal visits was no longer associated with the target outcome. Meanwhile, the odds of death for infants of mothers with more schooling, multiple pregnancies, and prematurity emerged as important characteristics. More in-depth research on the circumstances in which these deaths occur is crucial for a better understanding of the problem and for adopting strategies aimed at its reduction.

\section{Resumo}

Compararam-se fatores de risco para mortalidade infantil nos anos 2000/2001 e 2007/2008 em Londrina, Paraná, Brasil. Dados sobre nascidos vivos e óbitos infantis foram vinculados em base de dados única, $e$ usou-se análise de regressão em modelo hierárquico. No nível distal, foram de risco para mortalidade infantil, em 2000/2001, idade materna $<20$ e $\geq 35$ anos e escolaridade materna baixa. Em 2007/2008, idades maternas $\geq 35 e<20$ anos foram de risco, enquanto escolaridade baixa, protetora. Associaram-se à maior mortalidade infantil, no nível intermediário, em 2000/2001: gestação múltipla, filhos mortos e número insuficiente de consultas pré-natal, enquanto cesaria- na foi fator protetor. Em 2007/2008, apenas gestação múltipla foi de risco. Todos os fatores proximais associaram-se à maior mortalidade infantil em 2000/2001 e, em 2007/2008, apenas idade gestacional e Apgar no quinto minuto. Houve mudanças nos fatores de risco para a mortalidade infantil nos biênios analisados, o que pode estar relacionado à ampliação de políticas sociais e de ações básicas de saúde, e a modificações no padrão reprodutivo e social das mulheres.

Mortalidade Infantil; Fatores de Risco; Sistemas de Informação 


\section{Contributors}

H. G. Santos, S. M. Andrade, A. M. R. Silva, and W. O. Carvalho participated in the research project design, data tabulation and analysis, and writing and critical revision of the article. A. E. Mesas contributed to the data tabulation and analysis, and writing and critical revision of the article.

\section{Acknowledgments}

The authors wish to thank DECIT/SCTIE/Ministry of Health, CNPq, and Araucária Foundation for the research funding (Call for Projects PPSUS, Agreement 200/2010, case 19.516) and CNPq and CAPES for the scholarships.

\section{References}

1. Paim J, Travassos C, Almeida C, Bahia L, Macinko J. The Brazilian health system: history, advances, and challenges. Lancet 2011;377:1778-97.

2. Barros FC, Matijasevich A, Requejo JH, Giugliani E, Maranhão AG, Monteiro CA, et al. Recent trends in maternal, newborn, and child health in Brazil: progress toward Millennium Development Goals 4 and 5. Am J Public Health 2010; 100:1877-89.

3. Victora CG, Aquino EM, Leal MC, Monteiro CA, Barros FC, Szwarcwald CL. Maternal and child health in Brazil: progress and challenges. Lancet 2011; 377:1863-76.

4. Malta DC, Duarte EC, Escalante JJC, Almeida MF, Sardinha LMV, Macario EM, et al. Mortes evitáveis em menores de um ano, Brasil, 1997 a 2006: contribuições para a avaliação de desempenho do Sistema Único de Saúde. Cad Saúde Pública 2010; 26:481-91.

5. Morais Neto OL, Barros MBA. Fatores de risco para mortalidade neonatal e pós-neonatal na Região Centro-Oeste do Brasil: linkage entre bancos de dados de nascidos vivos e óbitos infantis. Cad Saúde Pública 2000; 16:477-85.
6. Nascimento EMR, Costa MCN, Mota ELA, Paim JS Estudo de fatores de risco para óbitos de menores de um ano mediante compartilhamento de bancos de dados. Cad Saúde Pública 2008; 24:2593-602.

7. Victora CG, Huttly SR, Fuchs SC, Olinto MT. The role of conceptual frameworks in epidemiological analysis: a hierarchical approach. Int J Epidemiol 1997; 26:224-7.

8. Machado CJ. A literature review of record linkage procedures focusing on infant health outcomes. Cad Saúde Pública 2004; 20:362-71.

9. American Academy of Pediatrics, Committee on Fetus and Newborn; American College of Obstetricians and Gynecologists; Committee on Obstetric Practice. The Apgar score. Pediatrics 2006; 117:1444-7.

10. Santhya KG. Early marriage and sexual and reproductive health vulnerabilities of young women: a synthesis of recent evidence from developing countries. Curr Opin Obstet Gynecol 2011; 23:334-9. 
11. Matijasevich A, Victora CG, Barros AJ, Santos IS, Marco PL, Albernaz EP, et al. Widening ethnic disparities in infant mortality in southern Brazil: comparison of 3 birth cohorts. Am J Public Health 2008; 98:692-8.

12. Almeida MF, Novaes HMD, Alencar GP, Rodrigues LC. Mortalidade neonatal no Município de São Paulo: influência do peso ao nascer e de fatores sócio-demográficos e assistenciais Rev Bras Epidemiol 2002; 5:93-107.

13. Geib LT, Freu CM, Brandão M, Nunes ML. Determinantes sociais e biológicos da mortalidade infantil em coorte de base populacional em Passo Fundo, Rio Grande do Sul. Ciênc Saúde Coletiva 2010; 15:363-70.

14. Coimbra LC, Silva AA, Mochel EG, Alves MT, Ribeiro VS, Aragão VM, et al. Fatores associados à inadequação do uso da assistência pré-natal. Rev Saúde Pública 2003; 37:456-62.

15. Lima LC. Idade materna e mortalidade infantil: efeitos nulos, biológicos ou socioeconômicos? Rev Bras Estud Popul 2010; 27:211-26.

16. Luke B, Brown MB. Elevated risks of pregnancy complications and adverse outcomes with increasing maternal age. Hum Reprod 2007; 22:1264-72.

17. Chan BC, Lao TT. Effect of parity and advanced maternal age on obstetric outcome. Int J Gynaecol Obstet 2008; 102:237-41.

18. Graner VR, Barros SM. Complicações maternas e ocorrências neonatais associadas às gestações múltiplas resultantes de técnicas de reprodução assistida. Rev Esc Enferm USP 2009; 43:103-9.

19. Hernandez AR, Silva CH, Agranonik M, Quadros FM, Goldani MZ. Análise de tendências das taxas de mortalidade infantil e de seus fatores de risco na cidade de Porto Alegre, Rio Grande do Sul, Brasil, no período de 1996 a 2008. Cad Saúde Pública 2011; 27:2188-96.

20. Travassos C, Martins M. Uma revisão sobre os conceitos de acesso e utilização de serviços de saúde. Cad Saúde Pública 2004; 20 Suppl 2:S190-8.

21. Estrella J, Ribeiro LM. Qualidade da gestão das condicionalidades do Programa Bolsa Família: uma discussão sobre o índice de gestão descentralizada. Rev Adm Pública 2008; 43:625-41.

22. Costa GD, Cotta RMM, Reis JR, Siqueira-Batista R, Gomes AP, Franceschini SCC. Avaliação do cuidado à saúde da gestante no contexto do Programa Saúde da Família. Ciênc Saúde Coletiva 2009; 14 Suppl 1:1347-57.

23. Secretaria Municipal de Saúde de Londrina, Autarquia Municipal de Saúde, Prefeitura de Londrina. Relatório de gestão 2002. http://www1.londrina. pr.gov.br/dados/images/stories/Storage/sec_sau de/relatorios_gestao/relatorio_gestao_2002.pdf (accessed on 23/Aug/2011).
24. Barros AJ, Santos IS, Matijasevich A, Domingues MR, Silveira M, Barros FC, et al. Patterns of deliveries in a Brazilian birth cohort: almost universal cesarean sections for the better-off. Rev Saúde Pública 2011; 45:635-43.

25. Soares ES, Menezes GMS. Fatores associados à mortalidade neonatal precoce: análise de situação no nível local. Epidemiol Serv Saúde 2010; 19: 51-60.

26. Menezes AM, Hallal PC, Santos IS, Victora CG, Barros FC. Infant mortality in Pelotas, Brazil: a comparison of risk factors in two birth cohorts. Rev Panam Salud Pública 2005; 18:439-46.

27. Araújo BF, Bozzetti MC, Tanaka AC. Mortalidade neonatal precoce no município de Caxias do Sul: um estudo de coorte. J Pediatr (Rio J.) 2000; 76:200-6.

28. Drevenstedt GL, Crimmins EM, Vasunilashorn S, Finch CE. The rise and fall of excess male infant mortality. Proc Natl Acad Sci USA 2008; 105:501621.

29. Assis HM, Machado CJ, Rodrigues RN. Perfis de mortalidade neonatal precoce: um estudo em uma maternidade pública de Belo Horizonte (MG), 2001-2006. Rev Bras Epidemiol 2008; 11:675-86.

30. Barros FC, Victora CG, Barros AJ, Santos IS, Albernaz E, Matijasevich A, et al. The challenge of reducing neonatal mortality in middle-income countries: findings from three Brazilian birth cohorts in 1982, 1993, and 2004. Lancet 2005; 365:847-54.

31. Romo A, Carceller R, Tobajas J. Intrauterine growth retardation (IUGR): epidemiology and etiology. Pediatr Endocrinol Rev 2009; 6 Suppl 3:332-6.

32. Lansky S, França E, Leal MC. Mortalidade perinatal e evitabilidade: revisão da literatura. Rev Saúde Pública 2002; 36:759-72.

33. Almeida MF, Alencar GP, França Jr. I, Novaes HMD, Siqueira AAF, Schoeps D, et al. Validade das informações das declarações de nascidos vivos com base em estudo de caso-controle. Cad Saúde Pública 2006; 22:643-52.

34. Gabani FL, Sant'Anna FHM, Andrade SM. Caracterização dos nascimentos vivos no município de Londrina (PR) a partir dos dados do Sinasc, 19942007. Ciênc Cuid Saúde 2010; 9:205-13.

35. Schoeps D, Almeida MF, Alencar GP, França Jr. I, Novaes HM, Siqueira AAF, et al. Fatores de risco para mortalidade neonatal precoce. Rev Saúde Pública 2007; 41:1013-22.

Submitted on 11/Jan/2012

Final version resubmitted on 05/Apr/2012

Approved on 17/Apr/2012 